\title{
Gender Representation in EFL Textbooks for Elementary Schools: A Content Analysis
}

\author{
Winda Khoirun Nisak ${ }^{1}$, Furaidah ${ }^{2}$, Gunadi Harry Sulistyo ${ }^{2}$ \\ ${ }^{1}$ Keguruan Bahasa-Universitas Negeri Malang \\ ${ }^{2}$ Pendidikan Bahasa Inggris-Universitas Negeri Malang
}

\begin{tabular}{l}
\hline INFO ARTIKEL \\
\hline Riwayat Artikel: \\
Diterima: 26-07-2019 \\
Disetujui: $19-03-2020$ \\
\hline
\end{tabular}

\section{Kata kunci:}

gender representation; english textbooks; content analysis; representasi gender; buku pelajaran bahasa inggris; analisis konten

\begin{abstract}
ABSTRAK
Abstract: This research is a study of assessing the representation of gender in elementary school textbooks used by an international curriculum that is widely used in 160 countries throughout the world. The content analysis used to lead the representation of the male and female on the textbooks. The findings of this study indicate that the gender representation formed in the textbook shows the existence of gender equality which is reflected in the balanced emergence of male and female characters that appear in textbooks, the prevalence of the professional picture of men and women and the balance of household activities reflected in the textbook.

Abstrak: Penelitian ini merupakan penelitian mengenai representasi gender di buku teks siswa sekolah dasar yang dipakai oleh kurikulum internasional yang tersebar luas di 160 negara di seluruh dunia. Konten analisis dipakai untuk melihat representasi dalam buku. Temuan dari penelitian ini menunjukkan bahwa konstruksi gender yang terbentuk dalam buku teks tersebut menunjukkan adanya kesetaraan gender yang tercermin dari berimbangnya kemunculan karakter laki laki dan perempuan yang muncul dalam buku teks, meratanya gambaran profesi laki-laki dan perempuan serta berimbangnya kegiatan rumah tangga yang tercermin dalam buku teks.
\end{abstract}

\author{
Alamat Korespondensi: \\ Winda Khoirun Nisak \\ Keguruan Bahasa \\ Universitas Negeri Malang \\ Jalan Semarang 5 Malang 65145 \\ E-mail: winda.side@gmail.com
}

Textbooks constitute one of the most important components in a language class. It serves as a language input for language learning in the classroom (Richards, 2001). Textbooks are expected to serve neutral learning sources, indiscriminate as well as non-bias in terms of content (Brugeilles \& Cromer, 2009). In attaining such an ideal, the Indonesian government has enacted a policy, which was stipulated in Republic of Indonesia's Minister of Education and Culture Regulation no. 8 the year 2016, article 2 paragraph 2 that accounts that the school textbooks should embody norm contents and positive values that prevail in the society. The content of the textbooks must not show any pornography, extremism, radicalism, gender bias and any further form of deviation. However, out of previous research, Lee \& Collins (2010), Gharbavi \& Ahmad (2012), Ullah \& Skelton (2013), Jannati (2014), Abdorreza (2014), Awayed (2015), Amerian \& Esmaili (2015), Yang (2016), Gebregeorgis (2016), Craeynest (2015) showed that bias is still observable within the observed textbooks which were used by schools year by year. One that most often appears in bias is gender bias.

According to Sunderland (2006), gender is taken as a "social correlate of sex"e and totally different with the term "sex". Sex refers to biological type of person in term of male or female, while gender tends to learned in every daily life through behaviours. Gander also can be notice as expectations associated with each sex (Scarpitti \& Anderson, 1992). Human is born to be male or female but learns to become male (masculine) or female (feminine). Gender expectations were constructed by social institution around. Lorber (1994) stated that system of gender also constructs one's life chances and direct male's and female's social, economic and self experiences. People construct their status of gender by sign and signal, it can be came from the way they dress, speak, walk, gesture.

(Scarpitti \& Anderson, 1992) notice that learning gender is important in structuring a social stereotypes and relation. For instance, a man's mindset about gender has been constructed since he was born to become a man, he should do several things that are assumed should be done by the man. From the moment we are born, the expectation for each sex begin to shape our gender identity (Scarpitti \& Anderson, 1992). Those social expectations may lead us to marginalization even violate one type of gender. That might happen because there are several social stereotypes of a male and female role in society that are not automatically true. 
As part of the discourse of EFL materials, school textbooks are intentionally designed to be read by school students (Damayanti, 2014). When reading these texts, they are automatically exposed to gendered discourse contained in the textbooks which in effect may contribute to shaping their ideas about gender. The lack female characters in texts and image in textbooks will limit the opportunity of female to identify their gender and validate how they should be in society. In other words, these stereotypes limit female student freedom to express themselves due to the limiting the roles which present in textbooks. These representations of male and female character have major influences on the student development and the socialization in real life setting (Singh, 2010).

Research regarding gender bias, in general, has been carried by most of the earlier researchers in Indonesia such as Damayanti (2014), Witjatmoko (2016), and Setyono (2018). Yet, from year to year, bias gender might be still found within most textbooks used as learning media in schools. Those previous studies dealt with textbooks in Indonesia that were published by domestic authors and publishers. This present study examined gender construction in textbooks which were developed, and published by an international publisher and were applied in 218 schools in Indonesia.

Two books representing the higher and lower grades at the primary level were chosen. At the lower level of primary school, second grade's books were chosen since this grade is in the middle class between first and third grade. Textbooks for the fifth grade also was chosen because it represented the higher grade in the elementary school. Primary education, specifically in elementary schools, is classified into two levels or grades, which is the lower grade and upper grade (Maryono, 2017). Students in the first, second and third grades in the elementary school are included in a lower grade, whilst the higher counterpart consists of fourth, fifth and sixth grade. The sample that represented the upper and the lower classes, was the 2nd and the 5th grades because both of them had a middle range position from the two classes were chosen. As a way of answering the questions regarding whether or not there is bias in the textbook that the researcher examines. As a consideration point in taking a stance, I refer Wienanda (2012) who has divided the percentage of the gap in three stages $0-15 \%$ considered to be balanced, $16-25 \%$ gap considered to be fairly balanced, and $>25 \%$ gap considered to be imbalanced.

This research investigates English textbooks for the second and fifth grade of elementary school which came from an international class in Indonesia. One sample that represents the upper and lower classes was chosen, namely 2 nd and 5 th grade because both of them had a middle range position from the two classes. Besides (Maryono, 2017) states that primary education, specifically in elementary schools, are classified into two levels or grades, which is the lower grade and upper grade.

\section{METHOD}

Considering the background described previously, the present study aims at examining roles depicted verbally and pictorially by a male and female character in selected textbooks and the proportion of male characters to female characters in texts and images. To determine how gender is represented in the textbooks, eight different categories based on (Diktas, 2011). There were gender occurrences in text and image, amount of talk, the occupations analysis, household chores and responsibilities, adjectives used, and spare time or hobbies. This research was assessed essential values as an academic effort in examining learning sources especialy textbooks. Supposing gender bias is still manifested within students' textbook, hence the link cycle of discrimination becomes complicated and indissoluble. In the quest of stopping such a vicious cycle, schools should choose neutral learning sources with no gender bias within. Gender construction can be depicted by the study which focuses on content analysis. Content analysis is a frequently applied method in social studies, its main purpose being the identification of patterns in texts. There are several categories which were used to depicts bias on the textbooks. The first one is visibility which means the frequency of males and females that appearing in textbooks. It is the easiest aspect of gender bias to examine, it refers to the picture of both kind of gender in tektbooks. When females do not appear as often as males in the text and image, the will implicit that women's accomplishments, or that they as human beings are not important enough to be included as stated by Stockdale (2006).

\section{FINDINGS}

The finding of the study as a result of analyzing gender bias in the English textbook for Elementary school students are the number of male and female characters in text and images, the number of active male and female, activities and responsibilities in household and family context of male/female, occupational roles of each character, activities mentioned in the text done by male/female characters, and adjectives used for females and males. The findings are presented in the order as follows:

\section{The Occurrence of Male and Female Characters in Texts and Images}

Stockdale (2006) states that visibility, referring to the number of male and female characters in the texts and illustrations is what shows the balance of gender representation. In order to reveal gender construction of the two books, the first step which was decided by the author is to analyse text and images appearing through characters inside the books. The first analysis is based on the way of appearance from characters. 
Table 1. Gender Occurrence in Textual of Male and Female Characters

\begin{tabular}{lcccl}
\hline & \multicolumn{3}{c}{ Textual } \\
\cline { 2 - 5 } Textbook & \multicolumn{2}{c}{ Male } & & Female \\
\hline & F & \% & f & $\%$ \\
\hline 2nd Grade & 40 & $52.6 \%$ & 36 & $47.4 \%$ \\
5th Grade & 76 & $62.3 \%$ & 46 & $37.7 \%$ \\
\hline
\end{tabular}

In accordance with the table, it is shown that the appearance of male characters in the textbook of second grade reaches 40 times as it counts $52.6 \%$ while the female characters appearance only reaches 36 times or it counts $47.4 \%$. In the fifth grade textbook, the number of appearance of male characters is 76 times as it counts $62.3 \%$ while female reaches 46 times or $37.7 \%$. From these data it can be concluded that the percentage of the appearance of characters in the male text in the text is more dominant or more frequent. The difference in the appearance of male and female characters in textual portrayals of second grade EFL textbooks is $5.2 \%$.

Table 2. Gender Occurrence in Pictorial of Male and Female Characters

\begin{tabular}{lcccl}
\hline \multirow{2}{*}{ Textbook } & \multicolumn{3}{c}{ Pictorial } \\
\cline { 2 - 5 } & \multicolumn{2}{c}{ Male } & Female \\
\hline & F & $\%$ & F & $\%$ \\
\hline 2nd Grade & 234 & $52.5 \%$ & 215 & $48.2 \%$ \\
5th Grade & 56 & $55.4 \%$ & 45 & $44.6 \%$ \\
\hline
\end{tabular}

The table has shown that the appearance of male characters in the second grade textbook inside the texts reaches 234 times as it counts $52.5 \%$, on the other hand, female characters appear 215 times or $48.2 \%$. In fifth grade textbook, male characters appear 56 times or $55.4 \%$ while female appear 45 times or $44.6 \%$. From these figures it can be concluded that the gab which is pictorial in the character pictorial also shows that male characters appear more often. However, the gab numbers obtained from this class 2 book consider as not biased because the gab range reaches $4.3 \%$.

\section{Number of Active Male and Female Characters in Text and Images}

After looking at gender percentage through the appearance of the character between male and female in the text, the researcher also observes characters activity inside the plot. Sunderland (2006) suggest that to portray the real-life conversation, both male and female characters should be an equal amount of talk. The researcher has used 'Amount of talk' analysis for each appearing character and finally reaches the final conclusion based on the number of male and female appearance and their speeches in the textbook.

Table 3. Amount of Talk (by turn) to Count Active Male and Female Characters in Text and Images

\begin{tabular}{ccccccl}
\hline $\begin{array}{c}\text { Amount of Talk } \\
\text { (by turn) }\end{array}$ & \multicolumn{2}{c}{ Male } & \multicolumn{2}{c}{ Female } & \multicolumn{2}{c}{ Total } \\
\cline { 2 - 7 } & $\mathrm{f}$ & $\boldsymbol{\%}$ & $\mathrm{f}$ & $\%$ & $\mathrm{f}$ & $\%$ \\
\cline { 2 - 7 } & 18 & $47.4 \%$ & 20 & $52.6 \%$ & 38 & $100 \%$ \\
\hline
\end{tabular}

Referring to the table 3, it is revealed that the number of male character speeches is 18 or $47.7 \%$ while the number of female speeches is 20 as it counts $52.6 \%$. This amount has shown that male characters have lesser speeches compared to female in the textbook, and we can conclude that female characters are more talkative.

\section{Activities and Responsibilities in Household Chores and Family Context of Male/Female}

The next analysis unit is activities and household responsibilities which often framed and appeared in the textbook. Michel, (1986) states that there are criteria that can depict the construction of gender imbalance, which is the depiction of the activities that they do include domestic task carried out in the home, contribute to the education of children and what are they doing in the house.

Table 4. Activities and Responsibilities in Household Chores and Family of Male/Female

\begin{tabular}{ccccccc}
\hline \multirow{2}{*}{$\begin{array}{c}\text { Activities and } \\
\text { Responsibilities }\end{array}$} & \multicolumn{2}{c}{ Male } & \multicolumn{2}{c}{ Female } & \multicolumn{2}{c}{ Total } \\
\cline { 2 - 8 } & F & $\%$ & f & $\%$ & f & $\%$ \\
\hline & 9 & $42.9 \%$ & 12 & $57.1 \%$ & 21 & $100 \%$ \\
\hline
\end{tabular}


The percentage of male and female figures appearing in this unit of analysis is the male got 9 times or $42.9 \%$ while the female characters got 12 times or $57.1 \%$. The gap between the two is $14.2 \%$. Descriptions of domestic work here include depictions of all activities involving the role of father or mother in terms of care and various work performed in the home setting. The conclusion of the description of domestic work carried out by male and female characters in class 2 and 5 textbooks is that female characters are more dominant doing housework such as caring for children while men are dominant by doing shopping and gardening. The character of the father and mother in both texts also experienced a difference where the dominant mother did housework together with her daughter while the father was more dominant doing housework along with his son.

\section{Occupational Roles of Male and Female Characters in Text and Images}

The next point of analysis to figure out gender proportion in the textbook is the imagery of the profession inside the two books. Porreca (1984) suggests that the activity and occupation attached to a particular gender may produce reflection in sexism.

\section{Table 5. Occupational Roles of Male and Female Characters in Text and Images}

\begin{tabular}{ccccccl}
\hline \multirow{2}{*}{$\begin{array}{c}\text { Occupational } \\
\text { Roles }\end{array}$} & \multicolumn{2}{c}{ Male } & \multicolumn{2}{c}{ Female } & \multicolumn{2}{c}{ Total } \\
\cline { 2 - 8 } & F & \% & f & \% & f & \% \\
\cline { 2 - 8 } & 55 & $57.9 \%$ & 40 & $47.2 \%$ & 95 & $100 \%$ \\
\hline
\end{tabular}

The previous table has shown that male characters professions appear 55 times which means $57.9 \%$ while female characters professions appear 40 times which means only $42.2 \%$. Based on the Occupational Roles aspecs, it can be concluded that the two books have attempted to show the males more often than the females for about $10.7 \%$ or male is more dominant than female.

\section{Spare Time and Leisure Time Activities}

Michel (1986) states that the aspects of stereotypes can be detected by images, attitudes, feelings and activities of a character in the text and images. The portrayal of leisure activity is also analysed to reveal gender construction inside the textbook. The portrayal of male and female characters is explained below:

Table 6. Spare Time and Leisure Time Activities in Percentages

\begin{tabular}{ccccccc}
\hline & \multicolumn{3}{c}{ Male } & \multicolumn{2}{c}{ Female } & \multicolumn{2}{c}{ Total } \\
\cline { 2 - 8 } Activities & $\mathrm{f}$ & $\%$ & f & $\%$ & f & $\%$ \\
& 47 & $56.6 \%$ & 36 & $43.4 \%$ & 83 & $100 \%$ \\
\hline
\end{tabular}

The table has shown that male characters activities reach 47 from the total 83 which means $56.6 \%$, while female characters activities reach only 36 as it counts $43.4 \%$. The male get higher number for aboub $13.2 \%$ than the female one. Male activities appeare varying, e.g. cycling, playing football, going to gym, jogging, table tennis and mount climbing. Another type of activities which been mentioned in the book are hunting, playing video game, fishing, and flying kites. In the other hand, female activities appear such as playing music, such piano and guitar, reading, writing and camping.

\section{Adjectives Used for Females and Males}

Diktas (2011) states that through observing the adjectives used, a lot of clues about the stereotypes and attitudes towards the sexes can be understood such as how females and males are portrayed and qualified, what they are meant to be or how they should look like. The percentage of characterization of both genders is explained in the next table:

Table 7. Adjectives Used for Females and Males in Percentages

\begin{tabular}{lllllll}
\hline Adjectives Used & \multicolumn{2}{c}{ Male } & \multicolumn{2}{c}{ Female } & \multicolumn{2}{c}{ Total } \\
\hline & $\mathrm{F}$ & $\boldsymbol{\%}$ & f & $\boldsymbol{\%}$ & f & \% \\
\cline { 2 - 8 } & 41 & $69.5 \%$ & 18 & $30.5 \%$ & 21 & $100 \%$ \\
\hline
\end{tabular}

In terms of adjective used, the table shown that male reach higer for about 41 times or about $69.5 \%$ while female appear 18 times from the total 59 which means $30.5 \%$. Adjectives are important indicators of gender study. Through observing the adjectives used, a lot of clues about the stereotypes and attitudes towards the sexes can be understood such as how females and males are portrayed and qualified, what they are meant to be or how they should look like. In the book, the adjectives above have been found out. The top two male adjectival appearance are sporty and wining a sports event while female moody and sporty. 


\section{DISCUSSION}

This research has described the representation of gender in two EFL texsbooks for elementary schools students. The instrument of this based on Diktas (2011) there are occurrence in illustrations and texts, amount of talk, analysis of the occupations, domestic roles and household responsibilities, adjectives used to qualify males and females, leisure/spare time activities, family roles and content analysis of the texts and pictures. (Ary, Razavieh, \& Jacob 1972) states that content analysis as the tool for identifying and prejudice bias in the textbook.

The finding of this study displayed in the form of the table to make easier for the reader to read. The proportion listed in the table directly leads to gap proportions, this is done because the gap is the final value seen in terms of determining whether gender bias -in the realm of the appearance of two types of gender- occurs in the textbook or not. The first proportion is on the textual visibility in the second-grade book Stockdale (2006) the visibility, referring to the number of male and female characters in the texts and illustrations is what shows the balance of gender representation. Meanwhile, Wienanda (2012) and Witjatmoko (2016)divides benchmark to determine the gender balance. The first one gap from $0-15 \%$ consider as balance, 16-25\% gap consider to fairly balance, and $>25 \%$ gap is considered as an imbalance.

In terms of visibility in the 2nd grades textbook, textual gaps of male and females reach $5.2 \%$, meanwhile the gap of pictorial visibility is $4.3 \%$. Furthermore, gap proportion in 5th grade for the textual visibility is $24.6 \%$. The last one, the gap of male and female visibility in 5th grades textbook for the pictorial aspects is $10.8 \%$. The visibility of male and female character on the textbook showed that there is an aspect of visibility which fairly biased. This aspect is the depiction of pictorial visibility in $5^{\text {th }}$ grades textbook. The visibility of the male character in the $5^{\text {th }} \mathrm{EFL}$ textbook reaches $24.6 \%$, which we can consider as fairly biased. In other hand, the visibility of male and female others is classified as balance considering that the gap found is worth less than $15 \%$

The next aspect is the amount of talk. Amount of talk is an important aspect which can be used to see the level of activity of male or female characters in the textbook. In both books, it is known that female characters are more active than male, as male characters only have a proportion of $47.7 \%$ while the female character gets a proportion of $52.6 \%$. It considered as balance since the gap less than $15 \%$. Sunderland (2006) suggest that to portray the real-life conversation, both male and female characters should be an equal amount of talk. Based on these data it can be seen that the two textbooks try to describe women as more active parties than men. This is an attempt to break the stereotype that women are more passive than men as (Holmes \& Meyerhoff 2003: 625) states that females are stereotypically considered to be the talkative sex.

The next aspect that constructs the description of male and female gender in textbooks is activities and responsibilities on household chores and family context of the male/female. This aspect is very important aspect because so far stereotypes and biases about men and women often come from the portrayal of these characters in the context of the household. Michel (1986) states that there are criteria that can depict the construction of gender imbalance, which is the depiction of the activities that they do include domestic task carried out in the home, contribute to the education of children and what are they doing in the house. However, the proportion of male emergence is less than the appearance of women. However both textbooks considered as balance in knows that the gap still less that $15 \%$ which is $14.2 \%$.

The last aspect is adjectives used for females and males. Diktas (2011) states that through observing the adjectives used, a lot of clues about the stereotypes and attitudes towards the sexes can be understood such as how females and males are portrayed and qualified, what they are meant to be or how they should look like. The male characters in the textbook are described as fond and proficient in sports, strong, like video games, have big muscles, and own pets. In other hand, women are depicted by the dominance characteristics such as friendly, moody, clever, jolly, bad-tempered, care, sporty, well organized, love clean, easy to nervous. Such depictions trigger bias for men and women since they are portrayed to be incomparable; where men are more dominantly depicted more in physical depiction and strength while women are portrayed more as emotional depictions. For the percentage of visibility of male and female in this aspect, there is bias found since the gap is more than $25 \%$.

\section{CONCLUSION}

The books that are used in this research cannot be generalized for all over EFL textbooks. The investigation also will limit itself to analysing gender bias based on text and images in the textbooks. In order to obtain comprehensive data, this study focused on texts and pictures of 2nd and 5th elementary schools which used in an international school. Meanwhile, this study takes the book of elementary school as the object that was written by overseas writer and publisher but it is used in Indonesian school.

These textbooks for the second and the fifth-grades of elementary schools used in all over the school in Indonesia male and female pictured balance based on several aspecs but imbalance in another aspecs. Bias and balance decide based on Wienanda (2012) who divides the percentage of the gap in three-stage $0-15 \%$ consider as balance, 16- $25 \%$ gap consider to fairly balance, and $>25 \%$ gap is considered as an imbalance. because of the gap is not more than $25 \%$ for each theme so this study concluded that this book is unbias or fair enough to percentage of the male and female character. however, in deeper analysis this book containing bias in several aspects like adjective and spare time responsibility which show male with several stereotypes. to unload those stereotype I suggest to the future researcher to use deep pictorial analysis or critical discourse analysis to reveal the bias in this book. 


\section{REFERENCES}

Abdorreza, T. (2014). Gender Representation in 'Top-Notch' Series: A Critical Discourse Analysis Perspective. International Journal of Research Studies in Psychology, 3(2), 39-51.

Amerian, M., \& Esmaili, F. (2015). Gender Representation in Iranian High School English Textbooks with a Critical Discourse Analysis Perspective. International Journal of Language Learning and Applied Linguistics World, 5(4), $277-289$.

Ary, D., Razavieh, A., \& Jacob, L. C. (1972). In Introduction to Research in Education. Belmont: Wads Worth/Thomson Learning.

Awayed-Bishara, M. (2015). Analyzing the Cultural Content of Materials Used for Teaching English to High School Speakers of Arabic in Israel. Discourse and Society, 26, 517-542.

Brugeilles, C., \& Cromer, S. (2009). Promoting Gender Equality through Textbooks: A Methodological Guide. Paris: United Nations Educational, Scientific and Cultural Organization.

Craeynest, F.V. (2015). Gender Representations in EFL Textbooks: A Quantitative and Qualitative Content Analysis. Ghent University, Belgium.

Damayanti, I. (2014). Gender Construction in Visual Images in Textbooks for Primary School Students. Indonesian Journal of Applied Linguistics, 3(2), 100-116.

Diktas, M. (2011). Gender Representations in EFL Course books. Presented at the $2^{\text {nd }}$ International Conference on New Trends in Education and Their Implications, Antalya: Turkey.

Gebregeorgis, M. Y. (2016). Gender construction through textbooks: The Case of an Ethiopian Primary School English Textbook. Africa Education Review, 13(3), 119-140.

Gharbavi, A., \& Ahmad Mousavi, S. (2012). The Application of Functional Linguistics in Exposing Gender Bias in Iranian High School English Textbooks. English Language and Literature Studies, 2(1), 85. https://doi.org/10.5539/ells.v2n1p85

Holmes, J., \& Meyerhoff, M. (2003). The Handbook of Language and Gender. London: Blackwell Publishing.

Jannati, S. (n.d.). Gender Representation in EFL Textbooks: A Case of ILI Pre-Intermediate Series. Journal of Applied Linguistics and Language Research, 2(3), 211-222.

Lee, J. F. K., \& Collins, P. (2010). Construction of Gender: A Comparison of Australian and Hongkong English Language Textbooks. Journal of Gender Studies, 19 (2), 121-137. https://doi.org/10.1080/09589231003695856

Lorber, J. (1994). The Social Construction of Gender. London: Sage Publication.

Maryono. (2017). Atmosfer Sekolah Dasar dan Implikasinya bagi Pendidikan Guru Sekolah Dasar. Jurnal Ilmiah Universitas Batanghari Jambi, 17(3), 103-113.

Richards, J. C. (2001). Curriculum Development in Language Teaching. Cambridge: Cambridge University Press.

Scarpitti, F. R., \& Anderson, M. L. (1992). Social Problem. New York: Harper and Row.

Setyono, B. (2018). The Portrayal of Women in Nationally-Endorsed English as a Foreign Language (EFL) Textbooks for Senior High School Students in Indonesia. Sexuality \& Culture, 22(4), 1077-1093. https://doi.org/10.1007/s12119-

Stockdale, A. D. (2006). Gender Representation in an EFL Textbook. University of Birmingham, Birmingham, UK.

Sunderland, J. (2006). Language and Gender: An Advanced Resource Book (1st ed.). https://doi.org/10.4324/9780203456491

Ullah, H., \& Skelton, C. (2013). Gender Representation in the Public Sector Schools Textbooks of Pakistan. Educational Studies, 39, 183-194.

Wienanda, K. W. (2012). An Analysis of VII Grade English Course Book Entitled English on Kky 1 In Term of Gender Balance of the Materials. Universitas Negeri Malang, Malang, Indonesia.

Witjatmoko, N. (2016). Gender Representation in Two EFL Textbooks Used in Grade VII of Junior High Schools. Unpublished Thesis. Universitas Negeri Malang, Malang.

Yang, C. C. R. (2016). Are Males and Females Still Portrayed Stereotypically? Visual Analyses of Gender in Two Hongkong Primary English Language Textbook Series. Gender and Education, 28, 674-692. 